\title{
PENGARUH PEMBERIAN BAHAN BELAJAR TERHADAP HASIL BELAJAR PADA MATAKULIAH RANGKAIAN DASAR LISTRIK
}

(suatu Studi di Jurusan Teknik Elektro UNJ)

\section{Abstrak}

Tujuan penelitian ini adalah untuk mengetahui seberapa besar pengaruh pemberian bahan ajar terhadap hasil belajar pada matakuliah rangakain dasar listrik.

Penelitian ini dilaksanakan di Jurusan Teknik Elektro Universitas Negeri Jakarta pada bulan Agustus 2003 sampai dengan September 2004. Metode yang digunakan adalah metode eksperimen. Langkah penelitian yang dilakukan dengan membuat dua kelompok sampel, kelompok $X_{1}$ diberikan bahan ajar, dan kelompok $X_{2}$ ditugaskan membaca buku literatur diperpustakaan. Sebelum pengujian hipotesis dilakukan uji persyaraatan. Ujian persyaratan analisis yang digunakan dalam penelitian ini adalah uji normalitas dan uji homogenitas. Uji normalitas dilakukan dengan menggunakan uji lilliefors, sedangkan uji homogenitas dengan menggunakan $c^{2}$ Dari hasil uji normalitas pada taraf signifikan a $=0.05$ diperoleh $L_{\text {hitung }}<$ $L_{\text {hitung }}$ atau $0.1721<0.190$, maka dapat dinyatakan data penelitian berdistribusi normal. Dari hasil uji homogenitas dilakukan dengan $c^{2}$ pada taraf signifikan a $=0.05$ diperoleh $L_{\text {hitung }}<L_{\text {tabel }}$ atau $0.1767<0.190$

Berdasarkan hasil perhitungan dengan mengunakan t-tes diperoleh $t_{\text {hitung }}$ sebesar 1,43 dan bila dikonsultasikan pada tabel distribusi t pada taraf signifikan $a=0.05$ diperoleh $t_{\text {tabel } 0.05:(38)}=$ 1.68 , atau $t_{\text {hitung }}<t_{\text {tabel }}, 1,43<1,48$, berarti pengaruh pemberian

*) Drs. Faried Wadjdi, M.Pd., adalah Universitas Negeri Jakarta 
bahan belajar terhadap hasil belajar maahasiswa pada matakuliah rangkaian dasar listrik lebih tinggi dari hasil belajar mahasiswa dengan memberikan tugas membaca literatur di perpustakaan. Dari hasil penelitian di atas dapat disimpulkan, pemberian bahan belajar sangat besar pengaruhnya terhadap hasil belajar mahasiswa pada mata kuliah rangkaian listrik.

\section{PENDAHULUAN}

Proses belajar-mengajar rnerupakan kegiatan melaksanakan kurikulum suatu lembaga pendidikan agar dapat mempengaruhi para peserta didik mencapai tujuan pendidikan yang telah ditetapkan. Tujuan pendidikan pada dasarnya mengantarkan para peserta didik menuju pada perubahan-perubahan tingkah laku, baik intelektual, moral, maupun sosial agar dapat hidup mandiri sebagai individu dan makhluk sosial. Dalam mencapai tujuan tersebut, peserta didik berinteraksi dengan lingkungan belajar yang diatur pendidik melalui proses pengajaran.

Pada proses pengajaran, baik pendidik maupun peserta didik melakukan kegiatan belajar. Belajar adalah suatu kegiatan yang harus dilakukan oleh setiap orang. Tanpa belajar tidak akan mungkin ada perubahan yang terjadi pada seseorang. Para ahli mengatakan bahwa belajar adalah suatu proses di mana suatu organisme berobah perilakunya sebagai akibat pengalaman. Selain itu akibat belajar seseorang juga akan memperoleh barbagai macam kecakapan, keterampilan, dan sikap.

Seorang dapat dikatakan belajar apabila terjadi perubahan dan perubahan yang terjadi tidak ada kaitannya dengan pertumbuhan seseorang. Belajar yang dilakukan seseorang memerlukan waktu. Menurut Muhibbin, belajar adalah kegiatan yang berproses dan merupakan unsur yang sangat fundamental dalam setiap penyelenggaraan jenis dan jenjang dengan beragam cara yang dilakukan sehingga diharapkan akan dapat meningkatakan hasil belajar. 
Peningkatan hasil belajar mahasiswa dapat dilakukan perguruan tinggi dengan menyiapkan fasilitas belajar seperti, gedung. laboratorium, perpustakaan dan berbagai sarana dan prasarana lainnya. Selain fasilitas-fasilitas tersebut, perguruan tinggi juga perlu mendorong dosen mencari alternatif-alternatif dalam meningkatkan hasil belajar. Salah satu alternatif peningkatan hasil belajar yang dapat dilakukan dosen adalah menyiapkan bahan ajar. Bahan ajar dirancang dan dikembangkan berdasarkan prinsip-prinsip instruksional yang baik sehingga dapat: 1) membantu mahasiswa dalam proses belajarnya, dan 2) membantu meringankan beban dosen dan sekaligus juga waktu penyajian materi, serta meningkatkan waktu untuk membimbing para mahasiswa.

Bahan belajar yang baik adalah bahan ajar yang: (1) dapat rnembangkitkan minat belajar mahasiswa, (2) mempunyai kejelasan tujuan instruksional, (3) menyajikan materi dengan struktur yang baik, (4) memberikan kesempatan kepada mahasiswa untuk berlatih dan memberikan umpan balik kepada mahasiswa, dan (5) menciptakan komunikasi dua arah.

Berdasarkan uraian di atas, dengan mempergunakan bahan ajar, diharapkan mahasiswa dapat termotivasi belajar untuk belajar mandiri lebih baik. Oleh sebab itu, melalui penelitian ini peneliti ingin mengetahui ada tidaknya pengaruh pemberian bahan ajar rangkaian dasar listrik terhadap peningkatan basil belajar mahasiswa.

\section{Rumusan Masalah}

Berdasarkan latar belakang masalah di atas, maka makalah penelitian dapat di rumuskan sebagai berikut: Apakah ada pengaruh pemberian bahan ajar terhadap basil belajar pada mata kuliah rangkaian dasar listrik? 


\section{KAJIAN TEORI}

\section{Hakekat Bahan Belajar}

Dalam perkuliahan, biasanya dosen dianggap sebagai satu-satunya sumber belajar/informasi bagi mahasiswa. Hal ini dapat diamati dengan kebiasaan mahasiswa mencatat apa yang disampaikan dosen selama dalam perkuliahan. Apabila tugas yang diberikan dosen menuntut proses penyelesaian yang menggunakan beberapa tingkat atau tidak sama dengan contoh yang diberikan, maka biasanya mahasiswa tidak dapat menyelesaikannya karena itu, tugas diselesaikan bersama-sama dalam ruang kuliah. Dugaan bahwa dosen sebagai salah satu sumber belajar mahasiswa adalah didasarkan atas pengamatan tentang sedikitnya jumlah mahasiswa yang membaca di perpustakaan. Padahal perpustakaan adalah sebagai pusat sumber belajar (learning resource centre).

Dikatakan sebagai pusat sumber belajar karena segala sesuatu dari yang berbentuk sebuah ruangan sampai dengan suatu bangunan bertingkat yang rumit yang didisain dan diatur secara khusus dengan tujuan untuk menyimpan, merawat, mengembangkan dan memanfaatkan koleksi sumber belajar, baik dalam bentuk bahan cetak maupun baahan non cetak oleh pelajar, baik secara individual maupun dalam kelompok kecil.

Untuk mengantisipasi kondisi seperti tersebut di atas, hendaknya seorang dosen mencari berbagai alternatif yang dapat merangsang mahasiswa untuk aktif belajar mandiri. Menurut Koesnadi Hardjapamekas yang dikutip oleh Ruseffendi, bahwa guru/dosen yang baik (berkualifikasi) adalah guru/dosen yang menguasai bidang studi dan mampu menggunakan metode yang tepat dalam setiap materi yang akan disampaikanya. Metode yang paling baik bagi mahasiswa dalam meningkatkan pengetahuan dan wawasannya adalah dengan membaca. Membaca merupakan bagian utama dari kehidupan seorang mahasiswa. Dengan kebiasaan membaca tentu akan dapat memperkaya pengetahuan dan wawasan mahasiswa. 
Untuk memperkaya pengetahuan dan wawasan mahasiswa serta memudahkan mahasiswa belajar, hendaknya setiap mata kuliah mempunyai bahan ajar.

Bahan ajar, modul, diktat dan buku-buku lainnya merupakan sumber belajar bagi mahasiswa. Sumber belajar dalam proses belajar adalah mentrasmisikan ransangan atau sebagian informasi kepada si pebelajar (mahasiswa). Menurut Fred dan Hendry, sumber belajar (learning resources) adalah suatu set bahan atau situasi belajar yang dengan sengaja diciptakan agar siswa secara individual dapat belajar. Belajar dengan mengutamakan sumber belajar adalah sistem belajar yang berorentasi pada siswa yang diatur sangat rapi untuk belajar individual sehingga memungkinkan keseluruhan kegiatan belajar dilakukan dengan mempergunakan sumber belajar, baik manusia maupun bahan belajar non manusia dalam situasi belajar yang diatur secara efektif.

Sumber belajar yang dipakai dalam pendidikan adalah suatu sistem yang terdiri dari sekelompok bahan atau situasi yang diciptakan dengan sengaja dan dibuat agar memungkinkan mahasiswa dapat belajar secara individual. Sumber belajar harus memenuhi persyaratan sebagai berikut:

1. harus dapat tersedia dengan cepat,

2. harus dapat memungkinkan siswa untuk memacu diri sendiri, dan

3. harus bersifat individual. Misalnya harus dapat memenuhi sebahagian kebutuhan para mahasiswa dalam belajar mandiri.

Menurut Paulina dan Purwanto, bahan ajar yang baik ditulis dan dirancang sesuai dengan prinsip-prinsip instruksional. Bahan ajar biasanya dilengkapi dengan pedoman untuk mahasiswa dan pedoman untuk pengajar. Fungsi pedoman bagi mahasiswa adalah untuk mempermudah mahasiswa mempelajari bahan ajar.

Bahan ajar yang baik, adalah bahan ajar yang dilengkapi dengan berbagai macam ilustrasi. Ilustrasi mempunyai peranan penting 
dalam bahan ajar, karena ilustrasi tersebut dapat memperjelas konsep, pesan, gagasan atau ide. Selain itu, ilustrasi yang menarik ditambah dengan tata letak yang baik, akan dapat membuat mahasiswa semakin senang untuk mempelajari bahan ajar.

Di samping komponen-komponen bahan ajar dengan beragam ilustrasi, bahan ajar yang menarik adalah bahan ajar yang menggunakan ekspresi tulis yang efektif. Ekspresi tulis yang baik akan dapat mempermudah pengkomunikasian pesan, gagasan, ide atau konsep yang disampaikan pada mahasiswa.

\section{Hakikat Rangkaian Dasar Listrik}

Dalam peralatan listrik atau alat-alat elektronika, terlihat beberapa komponen, di mana komponen yang satu dengan komponen yang lain saling bersambung. Terhubungnya komponen yang satu dengan komponen lainnya dapat dikatakan bahwa komponen tersebut telah terangkai.

Terangkainya komponen-komponen tersebut dengan sumber listrik mengakibatkan arus mengalir dalam rangkaian tersebut. Besar kecilnya arus mengalir dalam rangkaian tersebut ditentukan oleh besar kecilnya hambatan atau pada besar kecilnya sumber tegangan yang mensuplai rangkaian tersebut.

\section{Belajar dan Hasil Belajar}

Manusia belajar karena ingin tahu dan ingin mengembangkan tingkah laku yang efektif dan efisien dalam mencapai tujuan. Hal ini berarti bahwa dengan belajar, seseorang dapat merobah tingkah lakunya, yaitu: dari hal-hal yang sebelumnya tidak dapat dilakukan. Dengan belajar, seseorang memperoleh kecakapan, pengertian, keterampilan, kegemaran, sikap, dan kepuasan.

Menurut Hilgard dan Bower, belajar dapat diartikan sebagai perubahan tingkah laku yang relatif permanen, dan tidak disebabkan oleh adanya proses kedewasaan. Menurut Gagne seperti yang dikutip oleh Dahar, belajar adalah suatu proses di mana suatu 
organisme berubah prilakunya sebagai akibat pengalaman. Bell Gredler mengatakan bahwa belajar adalah proses orang memperoleh berbagai kecakapan, keterampilan, dan sikap.

Sudjana mengatakan bahwa ada empat keadaan yang menyebabkan terjadinya belajar yaitu yang ditandai oleh adanya perubahan tingkah laku pada diri si pebelajar, yang berupa (1) kemampuan aktual dan potensial, (2) kemampuan yang berlaku dalam waktu relatif lama, (3) merupakan hasil dari pengalaman dan latihan, dan (4) perolehan melalui usaha. Keempat hal tersebut disebuat sebagai hasil belajar.

Menurut Gagne, ada lima kemampuan sebagai hasil belajar yaitu: (1) keterampilan intelektual (suatu kemapuan seseorang menjadi komponen suatu subjek sehingga ia dapat mengklasifikasikan, mengidentifikasi, mendemonstrasikan dan mengeneralisasi suatu gejala), (2) strategi kognitif (kemampuan seorang untuk bisa mengontrol aktifitas intelektualnya dalam mengatasi masalah yang dihadapi), (3) informasi verbal (kemampuan seseorang untuk menggunakan bahasa lisan maupun tulisan dalam mengungkapkan sesuatu masalah), (4) keterampilan motorik yaitu kemampuan seseorang untuk mengkoordinasikan semua gerak otot secara teratur dan lancar dalam keadaan sadar), dan (5) sikap (kecenbrungan dalam menerima dan menolak suatu objek sikap). Menurut Bugelski, pada sistem pembelajaran biasanya hasil belajar dipengaruhi oleh kualitas guru (dosen) dan kondisi sekolah, seperti ketersediaan alat-alat penunjang dalam belajar.

Secara umum, pembelajaran dilukiskan sebagai upaya orang yang bertujuan membantu orang belajar. Hal ini memberikan pengertian bahwa pembelajaran mempunyai titik berat pada semua kejadian yang bisa mempengaruhi secara langsung pada hasil belajar mahasiswa.

Sementara itu, hasil belajar dapat dilihat dari dua bentuk yaitu hasil belajar kognitif dan hasil belajar objektif. Hasil belajar koknitif yaitu, 
melalui pendekatan belajar mahasiswa telah ditempa jalur penalarannya kearah pemecahan masalah menurut tahapantahapan tertentu. Dengan demikian, mahasiswa tidak hanya menerima teori-teori semata, melainkan lebih dari itu, mereka dapat menerapkan teori-teori dan konsep yang mereka temukan sendiri melalui proses belajar. Sedangkan hasil belajar objektif adalah hasil belajar yang segera tidak tampak dengan segera, Karena itu, untuk mencapai hasil belajar objektif, mahasiswa harus melaewati pembuktian-pembuktian nyata dan pelaksanaan tugas berikutnya, di lingkungan sosial mahasiswa masing-masing. Jika mahasiswa tersebut telah mencapai tingkat kematangan belajar di dalam kelas, dan kemudian mereka dapat menciptakan kondisi objektif di lingkungan sosial sedemikan rupa sehingga memungkinkan menerapkan hasil belajarnya, maka hasil belajar objektif akan tampak melalui kemampuan mahasiswa dalam melaksanakan tugasnya melalui penerapan ilmu yang telah diperolah secara luas.

Menurut Gagne hasil belajar dapat diamati melalui kinerja mahasiswa. Kemampuan yang diperoleh sebagai hasil belajar disebut kemampuan yang dipelajari. Adapun hasil belajar dikelompokkan atas lima kamampuan yaitu: (1) keterampilan intelektual, (2) informasi verbal, (3) strategi kognitif, (4) sikap, dan (5) keterampilan motorik. Keterampilan intelektual merupakan suatu kemampuan yang membuat seseorang menjadi kompeten terhadap sesuatu objek, sehingga ia dapat mengklasifikasikan dan mengidentifikasi sesuatu gejala. Informasi verbal adalah kemampuan seseorang untuk dapat menggunakan bahasa lisan maupun bahasa tulisan dalam mengungkapkan sesuatu masalah. Strategi kognitif adalah kemampuan seseorang untuk dapat mengontrol aktifitas intelektual dalam mengatasi masalah yang dihadapinya. Sikap adalah sesuatu kecenderungan dalam menerima atau menolak obyek. Keterampilan motorik adalah kemampuan seseorang mengkoordinasikan semua gerakan secara teratur dan lancar dalam keadaan sadar. 
Kelima hasil belajar tersebut tercermin pada tujuan instruksional khusus, yang secara hirarki dijabarkan dari: (1) tujuan instruksional, (2) tujuan kurikuler, dan (3) tujuan institusional. Hirarki tujuan tujuan tersebut menurut Sukmadinata adalah sarana pendidikan suatu lembaga pendidikan. Tujuan kurikuler merupakan sasaran suatu bidang studi atau mata pelajaran. Tujuan institusional umumnya merupakan target yang harus dicapai oleh suatu pokok bahasan. Selanjutnya menurut Sadiman, tujuan instruksional khsusus adalah tujuan yang secara spesifik menyatakan tingkah laku yang dapat diukur dan diamati yang harus dikuasi oleh mahasiswa setelah melalui proses instruksional.

Semiawan mengatakan bahwa hasil belajar adalah kemampuan yang dicapai oleh mahasiswa setelah mengikuti program belajarmengajar sesuai dengan tujuan yang telah ditetapkan. Menurut Sabarti, informasi hasil belajar dapat diperoleh melalui tes. Menurut Semiawan tes hasil belajar adalah mengukur efek pengalaman yang secara relatif dicakup oleh suatu unit pengalaman yang distandarisasikan yaitu suatu rencana pelajaran. Menurut Gronlund, tes berguna untuk: (1) memperbaiki kesiapan peserta didik, (2) meningkatkan motivasi, (3) meningkatkan daya ingat dan transfer belajar, (4) memberi umpan balik mengenai keefektifan pengajaran, dan (5) membantu peserta didik dalam pemahaman konsep diri.

Dari uraian di atas dapat dikatakan bahwa hasil belajar adalah tingkat penguasaan tujuan instruksional khusus oleh mahasiswa yang diukur melalui tes atau ujian dan direpresentasikan oleh skor hasil tes. Makin banyak tujuan instruktional khusus yang dikuasai, makin tinggi hasil belajar atau skor tes yang dicapai. Sebaliknya, makin sedikit penguasaan tujuan instruksional khusus makin rendah skor tesnya. Keberhasilan belajar yang ditunjukkan oleh skor tes mahasiswa dalam pencapaian hasil belajar juga dipengaruhi oleh beberapa keadaan individu dan pelayanan yang diperoleh mahasiswa selama terjadi proses belajar-mengajar. 


\section{Kerangka Berpikir}

Seperti yang telah diuraikan di atas, bahan belajar rangkaian dasar listrik merupakan buku yang disediakan di perpustakaan Universitas Negeri Jakarta. Sebagian besar buku yang tersedia di perpustakaan tersebut adalah buku-buku berbahasa asing. Dengan banyaknya bahan ajar yang disediakan di perpustakaan, sesungguhnya hasil belajar mahasiswa yang mengambil mata kuliah rangkaian listrik akan lebih baik. Pada kenyataannya, rerata hasil belajar mahasiswa tersebut tidak memuaskan.

Apakah rendahnya hasil belajar rangkaian dasar listrik yang diperoleh mahasiswa ada kaitannya dengan rendahnya minat baca di perpustakaan? Untuk melihat kondisi tersebut, maka dalam penelitian ini, sekelompok mahasiswa yang mengikuti kuliah rangkaian dasar listrik I, ditugaskan untuk membaca buku literatur yang telah ditetapkan di perpustakaan. Sekelompok mahasiswa lain yang terpisah diberikan diktat bahan ajar. Diktat ini dibuat dengan karateristik yang sesuai dengan kurikulum yang akan diajarkan. Seminggu sebelum diajarkan diktat bahan ajar dibagikan kepada mahasisiwa, dan sekelompok mahasiswa lagi ditugaskan untuk membaca buku literatur di perpustakaan.

Diberikannya bahan ajar kepada sekelompok mahasiswa, sesunguhnya minat membaca mahasiswa akan lebih tinggi daripada mereka yang ditugaskan membaca di perpustakaan, karena membaca di perpustakaan sangat bergantung dengan kemampuan berbahasa Inggris mahasiswa.

\section{METODOLOGI PENELITIAN}

Sesuai dengan rumusan masalah yang telah dikemukakan di atas, maka tujuan yang ingin dicapai dalam penelitian ini adalah untuk mendapatkan data empiris mengenai pengaruh pemberian bahan ajar terhadap peningkatan hasil belajar mata kuliah rangkaian dasar listrik. 
Penelitian ini dilakukan di Jurusan Teknik Elektro Fakultas Teknik Universitas Negeri Jakarta. Pertimbangan peneliti memilih lokasi ini adalah: (1) memudahkan peneliti memperoleh sampel, (2) mudah mengontrol kelompok yang dikontrol, dan (3) biaya yang dikeluarkan lebih murah. Penelitian ini dilakukan pada bulan Agustus 2003 sampai dengan November 2003.

Untuk mencapai tujuan penelitian ini, metode yang digunakan dalam penelitian ini adalah metode eksperimen. Mahasiswa yang diberikan bahan ajar rangkaan dasar listrik sebagai kelompok eksperimen, dan mahasiswa yang ditugasi membaca literatur di perpustakaan sebagai kelompok kontrol.

Populasi penelitian adalah mahasiswa Fakultas Teknik Universitas Negeri Jakarta yang kuliah pada tahun akademik 2003/2004. Yang menjadi sampel dalam penelitian ini adalah mahasiswa yang mengambil mata kuliah rangkaian dasar listrik pada semester genap. Teknik yang digunakan untuk pengambilan sampel adalah acak sederhana. Metode pengambilan sampel acak sederhana mempergunakan cara undian, dengan tujuan setiap unit mempunyai peluang yang sama untuk dipilih.

\section{HASIL PENELITIAN}

Nilai rata-rata mahasiswa yang diberikan bahan ajar rangkaian dasar listrik adalah 14.15 , dan mahasiswa yang ditugasi membaca literatur di perpustakaan adalah 11, 5 .

Pengujian hipotesis dilakukan dengan mempergunakan uji t. Hipotesis yang akan diuji adalah pengaruh pemberian bahan ajar terhadap hasil belajar rangkain dasar listrik mahasiswa. Hasil perhitungan diperoleh $t_{\text {hitung }}=1,43$, dan $t_{\text {tabel }}$ pada 0,95 =1,68 dengan $\mathrm{dk}=38$, Ternyata $\mathrm{t}_{\text {hitung }}<$ $t_{\text {tabel }}$ atau 1,43<1,68 artinya pengaruh pemberian bahan ajar terhadap hasil belajar mahasiswa pada mata kuliah rangkaian dasar listrik lebih tinggi daripada hasil belajar mahasiswa yang ditugasi membaca literatur di perpustakaan. Hasil pengujian hipotesis di atas adalah bahwa pemberian bahan ajar sangat besar pengaruhnya terhadap hasil belajar 
mahasiswa bila dibandingkan dengan mahasiswa ditugasi membaca literatur di perpustakaan.

\section{KESIMPULAN DAN SARAN}

\section{Kesimpulan}

Berdasarkan hasil penelitian di atas dapat ditarik kesimpulan sebagai berikut: Pertama, rata-rata hasil belajar rangkaian dasar listrik mahasiswa yang diberikan bahan ajar lebih tinggi daripada rata-rata hasil belajar mahasiswa yang ditugaskan membaca literatur di perpustakaan. Kedua, hasil perhitungan diperoleh bahwa $t_{\text {hitung }}<t_{\text {tabel }}$ atau 1,43<1,68 berarti ada pengaruh pemberian bahan ajar terhadap peningkatan hasil belajar mahasiswa pada mata kuliah rangkaian dasar listrik. Ketiga, terdapat peningkatan hasil belajar mahasiswa yang diberikan bahan ajar. Hal ini dapat dipengaruhi oleh materi yang di sajikan yang lebih terfokus, dan bahasa yang dipergunakan adalah bahasa Indonesia. Sebaliknya, mahasiswa yang ditugasi membaca literature di perpustakaan materi disetiap bahan bacaan tidak terfokus pada kurikulum. Selain itu, karena keterbatasan dalam bahasa inggris, minat baca diperpustakaan menurun, dan kecenderungan mahasiswa pergi ke perpustakaan hanya apabila ada penugasan.

\section{Saran}

Berdasarkan kesimpulan yang telah diuraikan di atas, berikut ini dikemukakan beberapa saran. Pertama: Untuk meningkatkan hasil belajar mahasiswa hendaknya setiap dosen dapat mebuat dan merancang bahan ajar. Kedua: Bahan ajar sebaiknya dilengkapi dengan ilustrasi sehinga tidak menimbulkan kebosanan waktu membacanya. Ketiga: Dengan menggunakan bahan ajar yang dirancang dengan baik, maka waktu yang tersedia bagi dosen untuk membimbing mahasiswa lebih banyak. 


\section{DAFTAR PUSTAKA}

Arief S. Sadiman. Perencanaan Sistem Instruksional. Jakarta: PPS IKIP Jakarta, 1992.

B.R. Bugelski. The Psichologi of Learning applied to Teaching. New York: The Bobb Merril co., 1984.

Cony Semiawan Stambioel, Prinsip dan Landasan Pengembangan Kurikulum. Jakarta: Mutiara Sumber Widya. 1990.

Fred Percival dan Hendry Ellington. Teknologi Pendidikan, diterjemahkan oleh Sudjarwo. Jakarta: Erlangga, 1988.

Gordon H. Bower \& Ernes R. Hilgard. Theories of Learning. Englewood Cliffs New Yersey: Prentice Hall, Inc., 1981.

Margaret E. Bell Gredler. Belajar dan Membelajarkan. Terjemahan oleh Munandir. Jakarta: Rajawali, 1991.

Muhibbin Syah, Psikologi Pendidikan Suatu Pendekatan Baru. Bandung: PT.

Nana Sudjana, Media Pengajaran. Bandung : CV. Sinar Baru Bandung, 1991

Nana Syaodih Sukmadinata. Prinsip dan Landasan Pengembangan Kurikulum . Jakarta: Depdikbud Proyek PLPTK. 1988.

Paulina Pannen dan Purwanto, Penulisan Bahan Ajar, Dalam Mengajar di Perguruan Tinggi, (Program Applied Approach) Bagian 4. Jakarta: UT. 1997

Ratna Wilis Dahar, Teori-teori Belajar: Jakarta, Erlangga, 1984.

Robert M. Gagne dan L.J. Briggs. Principles of Instructional Desing.

New York: Holt, Rinehard and Winston, 1989

Robert M. Gagne. Essential of Learning for Instruction. Hinsdale, illinois:

The Dryden Press, 1975.

Robert M. Gagne. The Conditions of Learning. New Yord: Holt, Rinehard and Winston, 1987.

Sabarti. A.M.K. Evaluasi Dalam Pengajaran Bahasa. Jakarta: Depdikbud-Dirjen Dikti, 1988

Yusufhadi Miarso, Defenisi Teknologi Pendidikan, Jakarta: CV. Rajawali, 1986. 